\title{
GLOBOMYCIN, A NEW PEPTIDE ANTIBIOTIC WITH SPHEROPLAST-FORMING ACTIVITY \\ II. ISOLATION AND PHYSICO-CHEMICAL AND BIOLOGICAL CHARACTERIZATION
}

\author{
Masatoshi Inukai, Mutsuo Nakajima, Masaaki Ōsawa, \\ Tatsuo Haneishi and Mamoru Arai \\ Fermentation Research Laboratories, Sankyo Co., Ltd. \\ 2-58, 1-chome, Hiromachi, Shinagawa-ku, Tokyo 140, Japan
}

(Received for publication December 16, 1977)

\begin{abstract}
The peptide antibiotic globomycin was extracted from the culture filtrate of Streptomyces halstedii No. 13912, purified on silica-gel columns and crystallized from acetonitrile to give colorless needles. It is a neutral substance with m.p. of $115^{\circ} \mathrm{C}$ and a molecular formula of $\mathrm{C}_{32} \mathrm{H}_{57} \mathrm{~N}_{5} \mathrm{O}_{9}$. On amino-acid analysis, it gave serine, threonine, glycine and an unidentified amino acid. It is soluble in methanol, ethyl acetate and chloroform but sparingly soluble in water. The antimicrobial spectrum of globomycin revealed its specific activity against Gramnegative bacteria. Formation of spheroplasts was observed when Escherichia coli was grown in the presence of globomycin, indicating inhibition of the bacterial cell wall synthesis as its mode of action.
\end{abstract}

As described in the previous paper, ${ }^{1)}$ globomycin was produced by four different strains of actinomycetes identified as Streptomyces halstedii No. 13912, Streptoverticillium cinnamoneum No. 15037 , Streptomyces neohygroscopicus subsp. globomyceticus No. 15631 and Streptomyces hagronensis No. 17834. Fermentation of globomycin by conventional submerged culture resulted in $10 \mu \mathrm{g} / \mathrm{ml}$ production of the antibiotic in a culture broth. This report presents isolation and physico-chemical as well as biological properties of globomycin.

\section{Isolation and Purification}

Isolation of globomycin was carried out from the culture broth obtained in a 600-liter fermentor as described in the preceding paper. ${ }^{1)}$ A 315 -liter aliquot of the culture broth was filtered with the aid of diatomaceous earth (1\%) and 300 liters of the filtrate thus obtained was extracted with 150 liters of methylene chloride, yielding 190 liters of the extract. The extract was concentrated under reduced pressure to give $300 \mathrm{ml}$ of the concentrate containing $2.4 \mathrm{~g}$ of globomycin in $80 \%$ recovery. The concentrate was washed with each $500 \mathrm{ml}$ of $0.05 \mathrm{~N} \mathrm{HCl}$ and $2 \% \mathrm{NaHCO}_{3}$ and twice with each $200 \mathrm{ml}$ of water saturated with $\mathrm{NaCl}$, successively, followed by drying on $\mathrm{Na}_{2} \mathrm{SO}_{4}$. After removal of the solvent, the concentrate was added dropwise to 2 liters of $n$-hexane, giving $76.3 \mathrm{~g}$ of an oil containing $2.2 \mathrm{~g}$ of globomycin. The oil was dissolved in a small amount of chloroform and adsorbed on a column packed with $200 \mathrm{~g}$ of silica gel in $1 \%$ methanol in chloroform. Globomycin was recovered in 3.4 liters of the eluate with $1 \sim 2 \%$ methanol in chloroform. Further purification was performed by chromatography on two successive columns of $150 \mathrm{~g}$ and $45 \mathrm{~g}$ silica gel with acetonitrile and $1 \sim 2 \%$ methanol in chloroform as eluents respectively. Active fraction obtained from the second chromatography was concentrated in vacuo to dryness to give $2.1 \mathrm{~g}$ of the crude globomycin. Repeated 
recrystallization of crude globomycin from acetonitrile resulted in $1.0 \mathrm{~g}$ of colorless needles of globomycin in $33 \%$ recovery from the culture filtrate.

\section{Physico-chemical Properties}

Globomycin, obtained as colorless needles from acetonitrile, was a neutral substance with m.p. $115^{\circ} \mathrm{C}$ and $[\alpha]_{D}^{25} \mathrm{O}\left(c 1, \mathrm{CHCl}_{3}\right)$. Found: C, 56.60; H, 8.69; N, 10.22\%. Calcd. for $\mathrm{C}_{32} \mathrm{H}_{57} \mathrm{~N}_{5} \mathrm{O}_{9}$. $\mathrm{H}_{2} \mathrm{O}: \mathrm{C}, 57.06 ; \mathrm{H}, 8.77 ; \mathrm{N}, 10.40 \%$. The molecular formula of globomycin was confirmed to be $\mathrm{C}_{32} \mathrm{H}_{57} \mathrm{~N}_{5} \mathrm{O}_{9}$ by FD mass $[\mathrm{M}+1]^{+}(m / e$ 656) and high resolution mass spectrum analysis. The compound crystallized from acetonitrile was found to be the monohydrate of globomycin as indicated in elementary analysis. The UV spectrum of globomycin showed only end absorption. The IR spectrum

Fig. 1. Infrared absorption spectrum of globomycin (KBr).

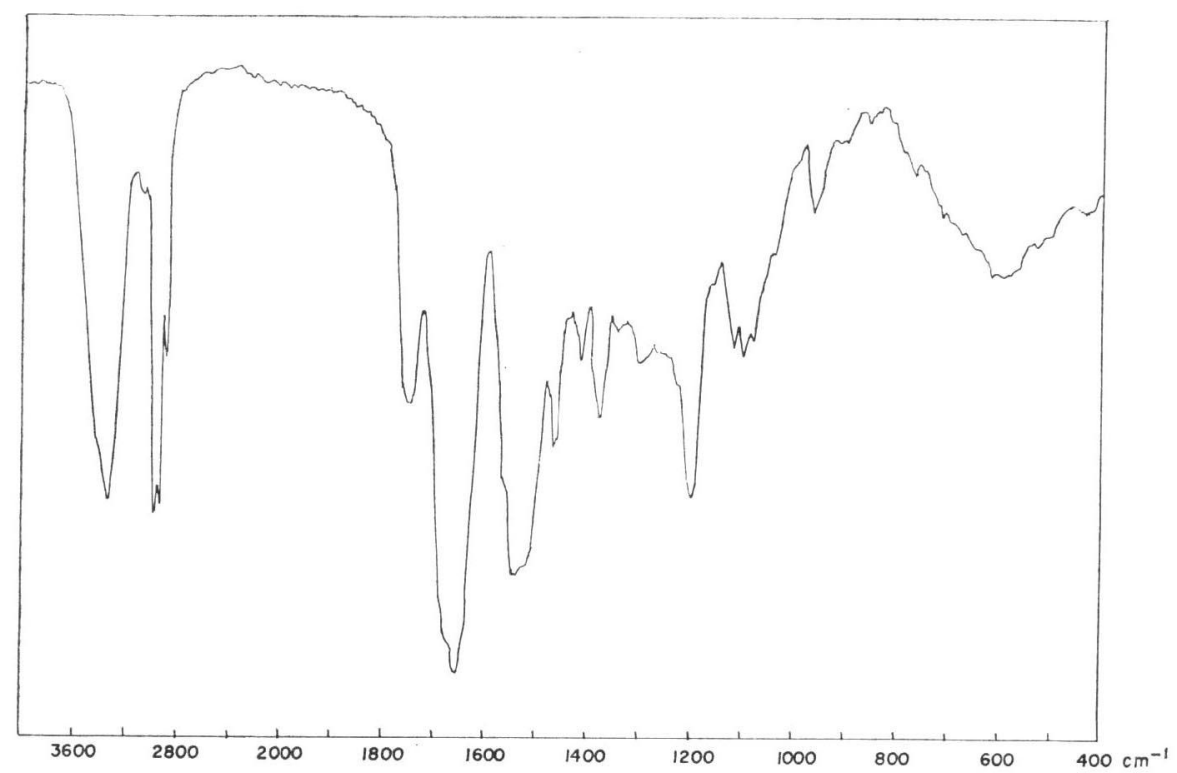

Fig. 2. $100 \mathrm{MHz}$ NMR spectrum of globomycin $\left(\mathrm{CDCl}_{3}\right)$.

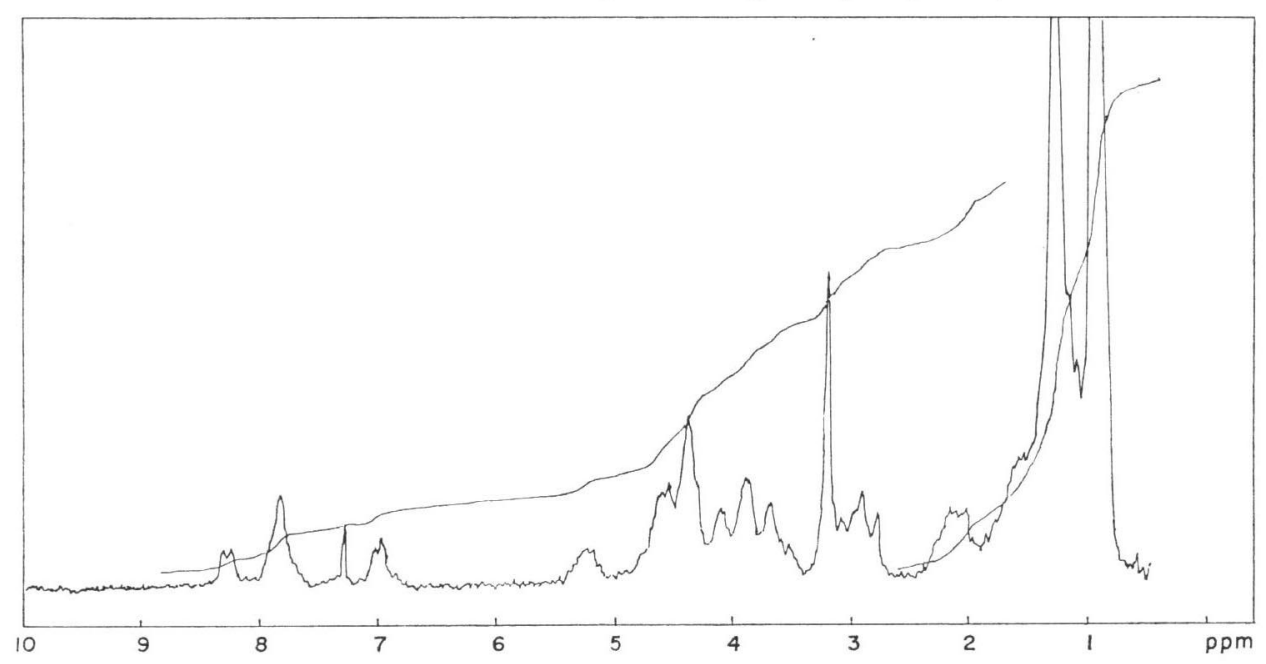


in a $\mathrm{KBr}$ pellet exhibited absorption peaks which correspond to a lactone or ester $\left(1740 \mathrm{~cm}^{-1}\right)$ and amide $\left(1670 \mathrm{~cm}^{-1}\right)$ linkages as shown in Fig. 1. The NMR spectrum indicated a characteristic peak at $3.2 \mathrm{ppm}$ of $\mathrm{N}$-methyl and strong peaks at the region of methyl and methylene as given in Fig. 2. A conventional Stein-Moore analysis of the hydrolysate of globomycin indicated the presence of each one mole of serine, threonine, glycine and one more unidentified amino acid which was later identified as allo-isoleucine. N-Methyl-leucine, also later found to exist as a constituent of globomycin, was not detected in this analysis because of its poor sensitivity to ninhydrin. Identification of these amino acids will be described in detail in the succeeding paper concerning structural elucidation of globomycin. Globomycin was soluble in methanol, ethanol, ethyl acetate, methylene chloride, chloroform, benzene and acetonitrile, but sparingly soluble in water and $n$-hexane. It showed a single spot on thin-layer chromatography on silica gel sheets with Rf values of 0.35 and 0.20 in the solvent systems of chloroform methanol (10:1) and acetonitrile, respectively, on which globomycin was detected by bioautography against E. coli SANK 71573 or spraying with sulfuric acid.

\section{Biological Properties}

The minimal inhibitory concentrations of globomycin against various microorganisms were

Table 1. Antimicrobial spectrum of globomycin

\begin{tabular}{|c|c|c|}
\hline Test organism* & Medium** & $\operatorname{MIC}(\mu \mathrm{g} / \mathrm{ml})^{* * *}$ \\
\hline Staphylococcus aureus FDA 209P JC-1 & 1 & $>100$ \\
\hline Bacillus subtilis PCI 219 & 1 & $>100$ \\
\hline Escherichia coli NIHJ JC-2 & 1 & 12.5 \\
\hline E. coli SANK 72375 & 1 & 12.5 \\
\hline E. coli SANK 71573 & 1 & 0.2 \\
\hline E. coli $\mathrm{B}$ & 1 & 0.4 \\
\hline Klebsiella pneumoniae PCI 602 & 1 & 0.2 \\
\hline K. pneumoniae 835 & 1 & 50 \\
\hline K. pneumoniae 846 & 1 & 25 \\
\hline Serratia marcescens SANK 73060 & 1 & 50 \\
\hline Shigella dysenteriae Hanabusa & 2 & 12.5 \\
\hline S. flexneri 2a Komagome & 2 & 12.5 \\
\hline S. sonnei $\mathrm{Oh}-\mathrm{hara}$ & 2 & 12.5 \\
\hline Salmonella typhi TD & 2 & 12.5 \\
\hline S. paratyphi A & 2 & 50 \\
\hline S. paratyphi $\mathrm{B}$ & 2 & 50 \\
\hline Pseudomonas aeruginosa 1046 & 1 & $>100$ \\
\hline Proteus vulgaris OX19 & 1 & $>100$ \\
\hline Mycobacterium smegmatis ATCC 607 & 1 & $>100$ \\
\hline Candida albicans YU 1200 & 3 & $>100$ \\
\hline Aspergillus oryzae SANK 11262 & 3 & $>100$ \\
\hline Trichophyton mentagrophytes SANK 11868 & 3 & $>100$ \\
\hline
\end{tabular}

$*$ Overnight seed cultures were diluted to $10^{-2}$ before streaking.

** Medium: 1. Heart infusion agar $+1 \%$ glycerol

2. Nutrient agar

3. Sabouraud dextrose agar

*** Minimal inhibitory concentration 
determined by a serial two-fold agar dilution method. The results are presented in Table 1. The antibiotic was only moderately active against most of the Gram-negative bacteria tested, but strongly against some highly sensitive strains of $E$. coli and Klebsiella pneumoniae. Globomycin was inactive against Gram-positive bacteria or fungi at a concentration of $100 \mu \mathrm{g} / \mathrm{ml}$. Although data are not available in this spectrum, globomycin showed no cross resistance with the known antibiotics, such as ampicillin, streptomycin, kanamycin, chloramphenicol and tetracycline. It was not cytotoxic to mouse $\mathrm{L}$ cells in tissue culture with minimal toxic concentration of $250 \mu \mathrm{g} / \mathrm{ml}$. The $\mathrm{LD}_{50}$ of globomycin was $115 \mathrm{mg} / \mathrm{kg}$ in mice ( $d d Y$, 今) by intraperitoneal injection, but mice tolerated with $400 \mathrm{mg} / \mathrm{kg}$ of the antibiotic by subcutaneous injection.

\section{Mode of Action}

When E. coli B was grown in the presence of $4 \mu \mathrm{g} / \mathrm{ml}$ of globomycin, reduction in optical

Plate 2. Spheroplasts of E. coli B formed in the presence of $4 \mu \mathrm{g} / \mathrm{ml}$ globomycin, scanning electron micrograph. A mark equals $1 \mu$.

A number of blebs are seen on the surface of spheroplasts.

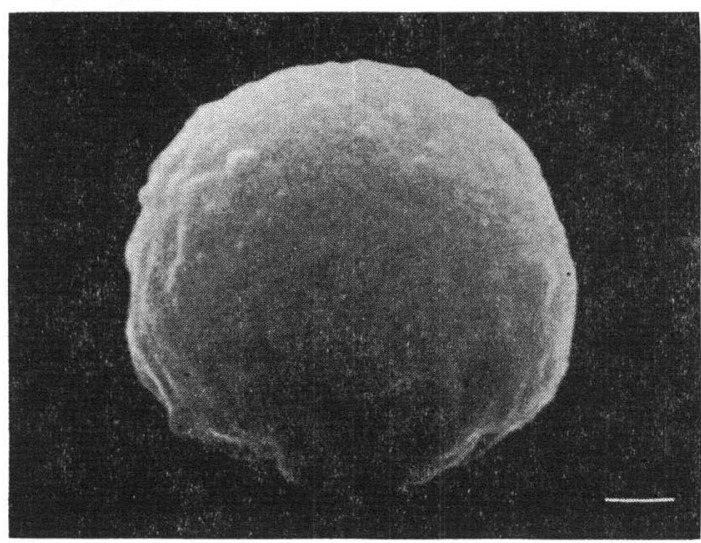

Fig. 4. Bactericidal activity of globomycin against $E$. coli $\mathrm{B}$. Viable cells were calculated by dilution with $0.85 \% \mathrm{NaCl}$.

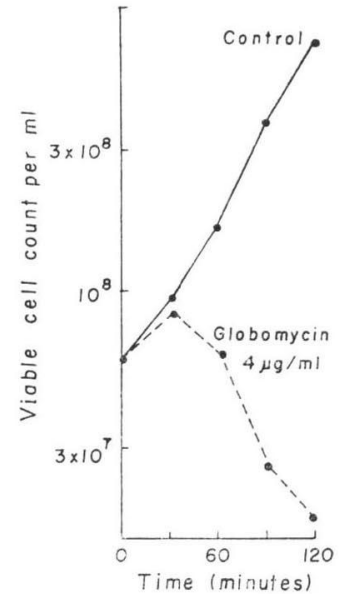

Plate 1. Normal Escherichia coli B cells, scanning electron micrograph. A mark equals $1 \mu$.

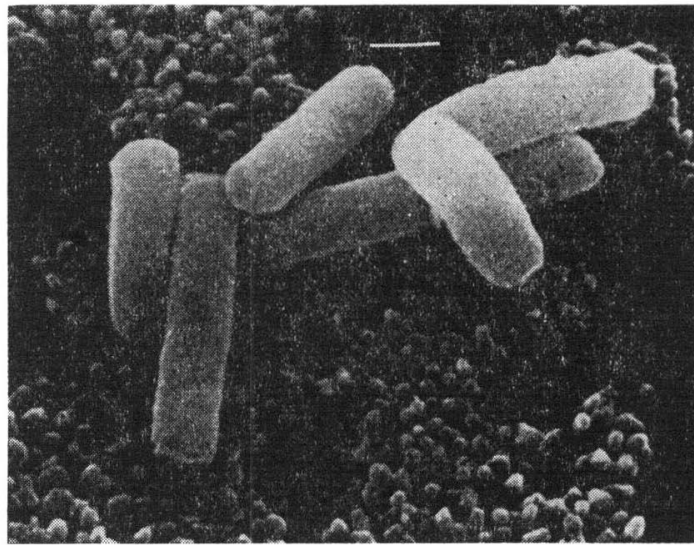

Plate 3. Spheroplasts of $E$. coli B formed in the presence of $4 \mu \mathrm{g} / \mathrm{ml}$ globomycin, scanning electron micrograph. A mark equals $1 \mu$. Sometimes a spheroplast is formed from the side of the cell like budding of yeasts (at the right side), and a burst spheroplast is also seen (at the left side).

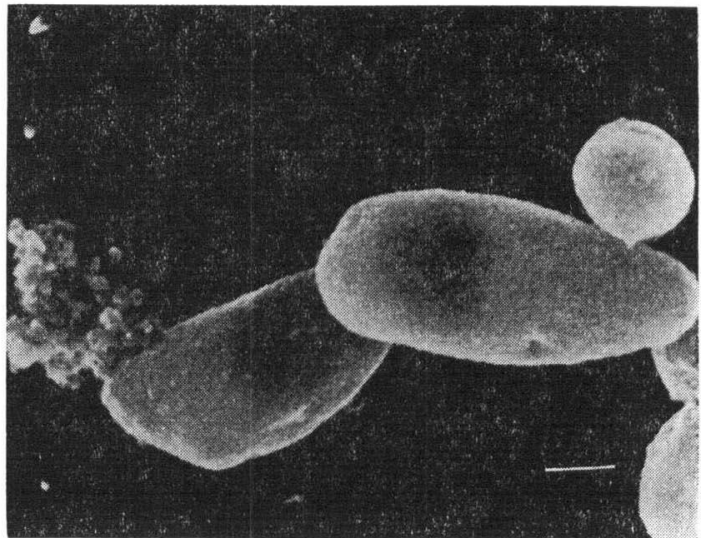


density at $550 \mathrm{~nm}$ was initiated after 90 -minute incubation at $37^{\circ} \mathrm{C}$ as shown in Fig. 3 . The viable cell numbers, however, already began to decrease at 30 minutes of incubation (Fig. 4). As shown in Plates $1 \sim 3$, formation of spheroplasts of $E$. coli cells in the isotonic medium was observed under microscope early at 30 minutes of incubation. The time lag observed between reduction in turbidity and killing of the cells may be explained by lysis of the spheroplasts under the condition of viable cell count. The details of further investigation on morphological changes of the cells in the presence of globomycin in relation to its mode of action will be reported elsewhere.

\section{Discussion}

Physico-chemical characterization of globomycin revealed that it is a peptide antibiotic with a molecular formula of $\mathrm{C}_{32} \mathrm{H}_{57} \mathrm{~N}_{5} \mathrm{O}_{9}$. Globomycin was only active against Gram-negative bacteria, inhibiting their cell wall synthesis as evident from spheroplast formation of $E$. coli cells in the presence of the antibiotic. Among known peptide antibiotics with inhibition of the bacterial cell wall synthesis, none has been recognized to have restricted activity against Gram-negative bacteria. Antimicrobial activity of bicyclomycin ${ }^{2,3}$ ) was found to be very similar to globomycin. It is mainly active against Gram-negative bacteria and is also reported to inhibit their cell wall synthesis. However, it is clearly differentiated from globomycin by its physico-chemical properties, especially by its non-peptide structure.

After completion of the present investigation, we noticed that physico-chemical as well as antibacterial properties of the antibiotic SF-19024) appeared to be related to those of globomycin. Side by side comparison of these two antibiotics was conducted by thin-layer chromatography on silica gel, amino acid analysis and mass spectrometry. Some differences were observed between these two antibiotics, such as slight differences in their Rf values on TLC, the existence of valine in SF-1902 and some difference in their mass spectrometric patterns. A final conclusion on the possible identity of these two antibiotics, however, must await further comparative studies. The producing organism of SF-1902 was identified as Streptomyces hygroscopicus, which resembles one of the producers of globomycin, S. neohygroscopicus subsp. globomyceticus No. 15631 in its hygroscopic nature of the aerial mycelia but the former is different from the latter by its warty surface of the spores.

\section{Acknowledgements}

The authors express their thanks to Dr. T. NIIDA, Meiji Seika Kaisha, for his kind supply of a sample of SF1902. Thanks are also due to Dr. S. Sugawara and his collaborators, Central Research Laboratories, Sankyo Co., Ltd. for the MIC test against pathogenic bacteria.

\section{References}

1) Inukai, M.; R. Enokita, A. Torikata, M. Nakahara, S. Iwado \& M. Arai: Globomycin, a new peptide antibiotic with spheroplast-forming activity. I. Taxonomy of producing organisms and fermentation. J. Antibiotics 31: 410 420, 1978

2) Miyoshi, T.; N. Mryairi, H. Aoki, M. Kohsaka, H. Sakai \& H. Imanaka: Bicyclomycin, a new antibiotic. I. Taxonomy, isolation and characterization. J. Antibiotics 25: 569 575, 1972

3) Nishida, M.; Y. Mine \& T. MATSubara: Bicyclomycin, a new antibiotic. III. In vitro and in vivo antimicrobial activity. J. Antibiotics 25: 582 593, 1972

4) Shomura, T.: Production of a new antibiotic SF-1902. Japan Kokai 77-64,491, May 27, 1977 